\title{
Synthesis and herbicidal activity of $\mathrm{N}$-(o-fluorophenoxyacetyl)thioureas derivatives and related fused heterocyclic compounds
}

\author{
Shao-Yong Ke ${ }^{a^{*}}$ and Si-Jia Xue ${ }^{\mathrm{b}}$ \\ ${ }^{a}$ College of Pharmacy, East China University of Science and Technology, Shanghai, \\ 200237, P. R. China \\ ${ }^{b}$ Department of Chemistry, Shanghai Normal University, Shanghai, 200234, P. R. China \\ E-mail: keshaoyong@163.com
}

\begin{abstract}
A series of $N$-(o-fluorophenoxyacetyl)thioureas derivatives (5) was synthesized using TBAB as phase transfer catalyst from corresponding $o$-fluorophenol in four steps. And four $O$ fluorophenoxyacetylimino- $2 \mathrm{H}-1,2$, 4-thiadiazolo $[2,3-a]$ pyrimidines (6) were prepared by oxidizative cyclization of 5 . The structures of these novel compounds were confirmed by IR, ${ }^{1} \mathrm{H}$ NMR and elemental analyses. The preliminary biological activity tests indicated that some target compounds had some herbicidal activity.
\end{abstract}

Keywords: Thiourea derivatives, synthesis, bioactivity

\section{Introduction}

Acylthiourea compounds are well known for their superior pesticidal activity, fungicidal activity, antiviral activity and regulating activity for plant growth. ${ }^{1-2}$ They are also important intermediates in organic synthesis. ${ }^{3}$ In addition, nitrogen heterocycles are extremely versatile building blocks for the manufacture of active compounds such as herbicides, fungicides, and insecticides in the agrochemical industry. ${ }^{4}$ In the process of searching for new active materials and precursor compounds, we adopted the method of combining active groups together to synthesize a series of $N$-(o-fluorophenoxyacetyl)thioureas $\mathbf{5}$ by introducing $O$ fluorophenoxyacetic acid and a pyrimidine ring into the acylthiourea structure using TBAB as phase transfer catalyst. According to a survey of the literature, 2H-1,2,4-thiadiazolo[2, 3a]pyrimidine derivatives are notable ALS inhibitors after the advent of sulfonylurea herbicides, which have comparative herbicidal activity, yet with superior selectivity. ${ }^{5-7}$ In view of these observations and in continuation of our earlier work on the synthesis and biological activities of $2 H-1,2,4$-thiadiazolo[2,3-a]pyrimidine derivatives, ${ }^{8-10}$ a series of $o$-fluorophenoxyacetylimino- 
$2 \mathrm{H}-1,2,4$-thiadiazolo[2,3-a]pyrimidines derivatives $\mathbf{6}$ were prepared from $\mathbf{5}$ by employing $\mathrm{Br}_{2}$ as the oxidant. ${ }^{11-12}$ Moreover, these compounds contain an inherently weak N-S bond, which can benefit plant absorption and metabolism. All the structures of these novel target compounds were confirmed by IR, ${ }^{1} \mathrm{H}$ NMR and elemental analyses. The preliminary biological activity tests indicated that some target compounds had some herbicidal activity.

The process for synthesis of target compounds is shown in Scheme 1.

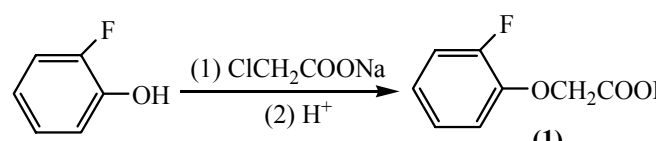

(1)

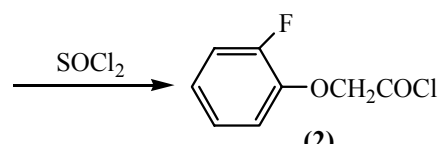

(2)

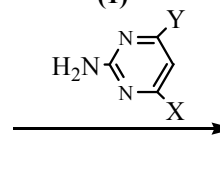

(4a 4e)

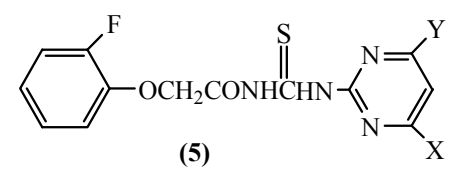

(3)

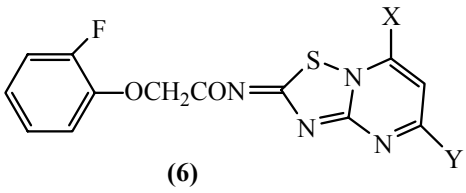

(6)
a. $\mathrm{X}=\mathrm{Y}=\mathrm{OCH}_{3}$
b. $\mathrm{X}=\mathrm{Y}=\mathrm{OC}_{2} \mathrm{H}_{5}$
c. $\mathrm{X}=\mathrm{Y}=\mathrm{CH}_{3}$
d. $\mathrm{X}=\mathrm{OCH}_{3} \mathrm{Y}=\mathrm{CH}_{3}$
e. $\mathrm{X}=\mathrm{OC}_{2} \mathrm{H}_{5} \quad \mathrm{Y}=\mathrm{CH}_{3}$

\section{Scheme 1}

\section{Results and Discussion}

The intermediate $o$-fluorophenoxyacetyl chloride (2) obtained by the reaction of $o$ fluorophenoxyacetic acid with thionyl chloride was treated with potassium thiocyanate using TBAB as phase transfer catalyst to give $o$-fluorophenoxyacetyl isothiocyanate (3). This intermediate was then treated with 4,6-disubstituted-2-aminopyrimidines $4 \mathbf{a}-4 \mathbf{e}$ to give compounds 5a-5e in good yield. Then the compounds 5a-5e were treated with bromine at room temperature to give the 5,7-disubstituted-2-(o-fluorophenoxyacetylimine)-2H-1,2,4thiadiazolo[2,3-a] pyrimidine derivatives 6 .

The use of phase transfer catalyst as a method of agitating a heterogeneous reaction system is gaining recognition. ${ }^{13-14}$ In search of improving methods to prepare the target acylthiourea by reacting acyl isothiocyanates with nucleophiles, we have found the use of TBAB as PTC can afford acyl isothiocyanates in good yield. In this paper, we have conducted our reaction using TBAB as phase transfer catalyst to synthesize the intermediate acylthioureas $\mathbf{5 a - 5 e}$, then the compounds 5a-5e which undergo room temperature reaction with bromine to give the corresponding compounds 6 . This provides a facile and convenient method for the synthesis of substituted imino- $2 \mathrm{H}-1,2,4-$ thiadiazolo[2,3-a]pyrimidine derivatives, with the advantages of simple operation, short reaction times and good yield. 
All the structures of the newly synthesized compounds were assigned on the basis of their elemental analyses and spectroscopic data, IR and ${ }^{1} \mathrm{H}$ NMR. All the compounds can be dissolved in DMF, DMSO and other nonprotonic solvents, but they are insoluble in chloroform and dichloromethane. The IR(KBr) spectrum of the series 5a-5e had strong N-H absorptions at about $3220 \mathrm{~cm}^{-1}$, and displayed absorptions at about $1680-1710 \mathrm{~cm}^{-1}, 1200 \mathrm{~cm}^{-1}$, which were assigned to $\mathrm{C}=\mathrm{O}$, and $\mathrm{C}=\mathrm{S}$ functions respectively. The medium-strong $v_{\mathrm{C}=\mathrm{O}}$ band in the IR spectra of all the compounds of series 5a-5e appeared at $1680-1710 \mathrm{~cm}^{-1}$, which is lower than that of the ordinary carbonyl absorption $\left(1730 \mathrm{~cm}^{-1}\right)$. The formation of an H-bond leads an increase of their polarity, so the strength of their double bond decreased, and the absorption moved to lower wavenumber. This possibility did not exist for compounds of series $\mathbf{6}$, hence, their $\mathrm{C}=\mathrm{O}$ absorption is at comparatively higher wavenumber. Even though, there was a delocalized pi-bond in them, the wavenumber was not so high as that of the ordinary carbonyl, at about $1720 \mathrm{~cm}^{-1}$. The ${ }^{1} \mathrm{H} \mathrm{NMR}$ $\left(d_{6}\right.$-DMSO) spectrum exhibited the singlet and multiplet signals at about $\delta 6.50$ and $\delta 7.10-8.50$ which were assigned to pyrimidine- $\mathrm{CH}$ and phenyl-CH protons, respectively. Most compounds of series 5a-5e exhibited signals at $8.80-9.50 \mathrm{ppm}$ or $12.20-13.50 \mathrm{ppm}$ which were assigned to the $\mathrm{N}-\mathrm{H}$ protons. The chemical shift of the proton of pyrimidine ring $\left(\mathrm{Py}-5^{\prime}-\mathrm{H}\right)$ can change greatly, depending on the nature of the substituents.

\section{Herbicidal Efficiency}

The preliminary herbicidal test results showed that the target compound 5a has high inhibitory activities against root and stalk of dicotyledon plants (such as Amaranthus retroflexus L.) in higher concentration (100 ppm), compound $\mathbf{6 d}$ has some inhibitory activity against the roots and stalks of dicotyledon plants (such as Chenopodium serotinum L.and Amaranthus retroflexus L.)(Table 1).

Table 1. The inhibition percentage of some compounds to kinds of plants

\begin{tabular}{|c|c|c|c|c|c|c|c|}
\hline Compd & $\begin{array}{l}\text { Conc. } \\
\text { (ppm) }\end{array}$ & $\begin{array}{c}\text { Inhibition } \\
(\%)\end{array}$ & $\begin{array}{c}\text { Echinochloa } \\
\text { crusgallis } \\
\text { L. }\end{array}$ & $\begin{array}{c}\text { Sorghum } \\
\text { bicolot }\end{array}$ & $\begin{array}{c}\text { Digitaria } \\
\text { sanguinalis } \\
\text { (L.) } \\
\text { Scop } \\
\end{array}$ & $\begin{array}{l}\text { Amaranthus } \\
\text { retroflexus } L .\end{array}$ & $\begin{array}{c}\text { Chenopo } \\
\text { dium } \\
\text { serotinum } \\
\text { L. }\end{array}$ \\
\hline \multirow{4}{*}{$5 a$} & \multirow{2}{*}{50} & The stalk & 0 & 20 & 0 & 80 & 30 \\
\hline & & The root & 10 & 20 & 0 & 80 & 30 \\
\hline & \multirow{2}{*}{100} & The stalk & 10 & 20 & 0 & 85 & 60 \\
\hline & & The root & 20 & 30 & 0 & 85 & 70 \\
\hline \multirow{4}{*}{$6 d$} & \multirow{2}{*}{50} & The stalk & 0 & 0 & 10 & 10 & 40 \\
\hline & & The root & 0 & 0 & 10 & 30 & 50 \\
\hline & \multirow{2}{*}{100} & The stalk & 10 & 0 & 30 & 10 & 50 \\
\hline & & The root & 10 & 0 & 40 & 40 & 60 \\
\hline
\end{tabular}




\section{Experimental Section}

General Procedures. All precursor substances are commercial products of chemical or analytical grade purity. Sulfuric chloride was redistilled and potassium thiocyanate was baked before use. 4, 6-Disubstituted 2-amino-pyrimidines 4a-4e were prepared by the literature method. ${ }^{15}$

The melting points were determined on an XT4A micro digital melting point apparatus and are uncorrected. The IR spectra were recorded in the region $4000-400 \mathrm{~cm}^{-1} \mathrm{KBr}$ discs on a Nicolet5DX FT-IR spectrophotometer. The ${ }^{1} \mathrm{H}$ NMR spectra were obtained on a Varian-300-54 spectro-meter in $d_{6}$-DMSO using TMS as internal reference. The $\mathrm{C}, \mathrm{H}$ and $\mathrm{N}$ analyses were repeated twice by elemental microanalyses. Thin layer chromatography (TLC) analyses were carried out on $5 \times 20 \mathrm{~cm}$ plates coated with silica gel $\mathrm{GF}_{254}$ type 60 (50-250 mesh) using a ethyl acetate-petroleum ether mixture $(1: 2)$ as solvent.

\section{General procedures for the preparation of the target compounds 5a-5e, 6a-6e}

$o$-Fluorophenol $(0.05 \mathrm{~mol}), 50 \%$ sodium hydroxide aqueous $(0.055 \mathrm{~mol})$, ethanol $(3 \mathrm{~mL})$ were placed in a dried round-bottomed flask containing a magnetic stirrer bar and stirred at room temperature for about $20 \mathrm{~min}$. Then sodium chloroacetate aqueous $(0.05 \mathrm{~mol})$ was added and the mixture was stirred at refluxed temperature for $1 \mathrm{~h}$. During the process, the $\mathrm{pH}$ of the react system was kept at 9-10. After this, $30 \mathrm{~mL}$ of water was added and the solution was acidified by hydrochloric acid to yield precipitate. The resulting precipitate was collected and recrystallized from $\mathrm{C}_{2} \mathrm{H}_{5} \mathrm{OH}-\mathrm{H}_{2} \mathrm{O}$ to give pure $o$-fluorophenoxyacetic acid 1. m.p. $134-136{ }^{\circ} \mathrm{C}$, Yield, $84 \%$.

$o$-Fluorophenoxyacetic acid (1) $(0.05 \mathrm{~mol}), 10 \mathrm{~mL}$ of toluene and sulfuric chloride $(15 \mathrm{~mL})$ were placed in a dried round-bottomed flask containing a magnetic stirrer bar and stirred at about $50^{\circ}$ for $2 \mathrm{~h}$. Then excess sulfuric chloride was removed under reduced pressure to give a clear solution of $o$-fluorophenoxyacetyl chloride (2). To a solution of potassium thiocyanate $(0.15$ mol) in $10 \mathrm{~mL}$ of acetonitrile, the clear solution of $o$-fluorophenoxyacetyl chloride 2 and $3 \%$ TBAB in acetonitrile were added. The flask with the reaction mixture was immersed in an oil bath for about $45 \mathrm{~min}$ and then the reaction mixture was filtered off to yield an orange-red solution 3. Then equimolar quantity of 4,6-disubstituted-2-aminopyrimidines $4 \mathbf{a}-4 \mathbf{e}$ was added and the reaction mixture was refluxed for about $1 \mathrm{~h}$. The reaction was monitored by TLC. At the end of the reaction, the resulting precipitate was collected by filtration and recrystallized from EtOH or DMF-EtOH to yield compound 5a-5e.

To a solution of compound 5 in $15 \mathrm{~mL}$ of $\mathrm{CHCl}_{3}$ (or acetone), an equimolar quantity of bromine was added dropwise with cooling in a water bath. After addition, the flask with the reaction mixture was stirred at room temperature for about $2 \mathrm{~h}$. At the end of the reaction, the resulting precipitate was collected by filtration, the crude product was purified by column chromatography using petroleum/AcOEt as eluents to yield corresponding compound $\mathbf{6}$. 
Characterization of Target Compounds $N^{\prime}(4,6$ 6-disubstituted pyrimidin-2-yl)- $N-(o-$ fluorophenoxyacetyl)thioureas (5a-5e)

Compound 5a. Yield: $72 \%$ m.p. $181-183{ }^{\circ} \mathrm{C}$. IR $\left(\mathrm{cm}^{-1}\right)$ : 3225(N-H), $1689(\mathrm{C}=\mathrm{O}), 1605(\mathrm{C}=\mathrm{N})$, 1232(C=S). ${ }^{1} \mathrm{H}$ NMR (d -DMSO$) \delta: 3.84\left(\mathrm{~s}, 6 \mathrm{H}, \mathrm{OCH}_{\underline{3}}\right), 4.32\left(\mathrm{~s}, 2 \mathrm{H}, \mathrm{OCH}_{2}\right), 6.65(\mathrm{~s}, 1 \mathrm{H}$, pyrimidine-5-H), 7.32-8.15(m, 4H, phenyl-H), 9.24(s, 1H, NH), 12.60(s, 1H, NH). Anal. calcd. for $\mathrm{C}_{15} \mathrm{H}_{15} \mathrm{FN}_{4} \mathrm{O}_{4} \mathrm{~S}$ : C 49.18, H 4.10, N 15.30; found C 49.01, H 4.25, N 15.13.

Compound 5b. Yield: 74\%. m.p. 187-190 ${ }^{\circ} \mathrm{C}$. IR $\left(\mathrm{cm}^{-1}\right): 3228(\mathrm{~N}-\mathrm{H}), 1695(\mathrm{C}=\mathrm{O}), 1610(\mathrm{C}=\mathrm{N})$, 1238(C=S). ${ }^{1} \mathrm{H}$ NMR $\left(d_{6}\right.$-DMSO) $\delta: 1.54\left(\mathrm{t}, 6 \mathrm{H}, \mathrm{CH}_{\underline{3}}\right), 3.91\left(\mathrm{q}, 4 \mathrm{H}, \mathrm{OCH}_{2}\right), 4.45\left(\mathrm{~s}, 2 \mathrm{H}, \mathrm{OCH}_{2} \mathrm{CO}\right)$, 6.57(s, 1H, pyrimidine-5-H), 7.25-8.02(m, 4H, phenyl-H), 12.75(s, 1H, NH). Anal. calcd. for $\mathrm{C}_{17} \mathrm{H}_{19} \mathrm{FN}_{4} \mathrm{O}_{4} \mathrm{~S}$ : C 51.78, H 4.82, N 14.21; found C 51.56, H 4.71, N 14.38.

Compound 5c. Yield: 62\%. m.p. $>250{ }^{\circ} \mathrm{C}$. IR $\left(\mathrm{cm}^{-1}\right): 3218(\mathrm{~N}-\mathrm{H}), 1706(\mathrm{C}=\mathrm{O}), 1606(\mathrm{C}=\mathrm{N})$, $1220(\mathrm{C}=\mathrm{S}) .{ }^{1} \mathrm{H}$ NMR $\left(d_{6}\right.$-DMSO $) \delta: 2.32\left(\mathrm{~s}, 6 \mathrm{H}, \mathrm{CH}_{3}\right), 4.15\left(\mathrm{~s}, 2 \mathrm{H}, \mathrm{OCH}_{2}\right), 6.28(\mathrm{~s}, 1 \mathrm{H}$, pyrimidine5-H), 7.35-8.10(m, 4H, phenyl-H), $9.08(\mathrm{~s}, 1 \mathrm{H}, \mathrm{NH}), 12.42(\mathrm{~s}, 1 \mathrm{H}, \mathrm{NH})$. Anal. calcd. for $\mathrm{C}_{15} \mathrm{H}_{15} \mathrm{FN}_{4} \mathrm{O}_{2} \mathrm{~S}$ : C 53.89, H 4.49, N 16.77; found C 53.65, H 4.62, N 16.58.

Compound 5d. Yield: $68 \%$ m.p. $212-216^{\circ} \mathrm{C} . \mathrm{IR}\left(\mathrm{cm}^{-1}\right): 3220(\mathrm{~N}-\mathrm{H}), 1698(\mathrm{C}=\mathrm{O}), 1618(\mathrm{C}=\mathrm{N})$, 1235(C=S). ${ }^{1} \mathrm{H}$ NMR $\left(d_{6}\right.$-DMSO) $\delta: 2.25\left(\mathrm{~s}, 3 \mathrm{H}, \mathrm{CH}_{\underline{3}}\right), 3.92\left(\mathrm{~s}, 3 \mathrm{H}, \mathrm{OCH}_{\underline{3}}\right), 4.24\left(\mathrm{~s}, 2 \mathrm{H}, \mathrm{OCH}_{2}\right)$, 6.32(s, 1H, pyrimidine-5-H), 7.18-7.94(m, 4H, phenyl-H), 9.38(s, 1H, NH), 12.32(s, 1H, NH). Anal. calcd. for $\mathrm{C}_{15} \mathrm{H}_{15} \mathrm{FN}_{4} \mathrm{O}_{3} \mathrm{~S}$ : C 51.43, $\mathrm{H} 4.29, \mathrm{~N} 16.00$; found $\mathrm{C} 51.61, \mathrm{H} 4.21, \mathrm{~N} 15.84$.

Compound 5e. Yield: 64\%. m.p. $218-223{ }^{\circ} \mathrm{C}$. IR $\left(\mathrm{cm}^{-1}\right): 3215(\mathrm{~N}-\mathrm{H}), 1700(\mathrm{C}=\mathrm{O}), 1620(\mathrm{C}=\mathrm{N})$, $1230(\mathrm{C}=\mathrm{S}) .{ }^{1} \mathrm{H} \mathrm{NMR}\left(d_{6}\right.$-DMSO) $\delta: 1.42\left(\mathrm{t}, 3 \mathrm{H}, \mathrm{OCH}_{2} \underline{\mathrm{CH}}_{3}\right), 3.96\left(\mathrm{q}, 2 \mathrm{H}, \mathrm{OCH}_{2} \mathrm{CH}_{3}\right), 2.18(\mathrm{~s}, 3 \mathrm{H}$, $\left.\mathrm{CH}_{3}\right), 4.35\left(\mathrm{~s}, 2 \mathrm{H}, \mathrm{OCH}_{2} \mathrm{CO}\right), 6.40(\mathrm{~s}, 1 \mathrm{H}$, pyrimidine-5-H), 7.20-8.15(m, 4H, phenyl-H), 9.42(s, $1 \mathrm{H}, \mathrm{NH}$ ). Anal. calcd. for $\mathrm{C}_{16} \mathrm{H}_{17} \mathrm{FN}_{4} \mathrm{O}_{3} \mathrm{~S}$ : C 52.75, H 4.67, N 15.38; found $\mathrm{C} 52.60, \mathrm{H} \mathrm{4.79,} \mathrm{N}$ 15.47 .

\section{5,7-Disubstituted-2-(o-fluorophenoxyacetylimine)-2H-1,2,4-thiadiazolo[2,3-a]pyrimidine}

\section{derivatives (6)}

Compound 6a. Yield: $86 \%$. m.p. $206-209{ }^{\circ} \mathrm{C}$. IR $\left(\mathrm{cm}^{-1}\right): 1718(\mathrm{C}=\mathrm{O}), 1624(\mathrm{C}=\mathrm{N}) .{ }^{1} \mathrm{H}$ NMR $\left(d_{6^{-}}\right.$ DMSO) $\delta: 3.78\left(\mathrm{~s}, 3 \mathrm{H}, \mathrm{OCH}_{3}\right), 3.86\left(\mathrm{~s}, 3 \mathrm{H}, \mathrm{OCH}_{3}\right), 4.36\left(\mathrm{~s}, 2 \mathrm{H}, \mathrm{OCH}_{2}\right), 6.59(\mathrm{~s}, 1 \mathrm{H}$, pyrimidine-5$\mathrm{H}), 7.28-8.12\left(\mathrm{~m}, 4 \mathrm{H}\right.$, phenyl-H). Anal. calcd. for $\mathrm{C}_{15} \mathrm{H}_{13} \mathrm{FN}_{4} \mathrm{O}_{4} \mathrm{~S}: \mathrm{C} 49.45, \mathrm{H} 3.57, \mathrm{~N}$ 15.38; found C 49.63, H 3.41, N 15.56 .

Compound 6b. Yield: $81 \%$. m.p. $201-205{ }^{\circ} \mathrm{C}$. IR $\left(\mathrm{cm}^{-1}\right): 1721(\mathrm{C}=\mathrm{O}), 1618(\mathrm{C}=\mathrm{N}) .{ }^{1} \mathrm{H}$ NMR $\left(d_{6^{-}}\right.$ DMSO) $\delta: 1.50\left(\mathrm{t}, 3 \mathrm{H}, \mathrm{CH}_{\underline{3}}\right), 1.58\left(\mathrm{t}, 3 \mathrm{H}, \mathrm{CH}_{3}\right), 3.85\left(\mathrm{q}, 2 \mathrm{H}, \mathrm{OCH}_{2}\right), 3.94\left(\mathrm{q}, 2 \mathrm{H}, \mathrm{OCH}_{2}\right), 4.42(\mathrm{~s}, 2 \mathrm{H}$, $\left.\mathrm{OCH}_{2} \mathrm{CO}\right), \quad 6.50(\mathrm{~s}, \quad 1 \mathrm{H}$, pyrimidine-5-H), 7.28-8.07(m, 4H, phenyl-H). Anal. calcd. for $\mathrm{C}_{17} \mathrm{H}_{17} \mathrm{FN}_{4} \mathrm{O}_{4} \mathrm{~S}$ : C 52.04, H 4.34, N 14.29; found C 52.18, H 4.17, N 14.42.

Compound 6d. Yield: 74\%. m.p. $237-239{ }^{\circ} \mathrm{C}$. IR $\left(\mathrm{cm}^{-1}\right): 1716(\mathrm{C}=\mathrm{O}), 1620(\mathrm{C}=\mathrm{N}) .{ }^{1} \mathrm{H}$ NMR $\left(d_{6^{-}}\right.$ DMSO) $\delta: 2.35\left(\mathrm{~s}, 3 \mathrm{H}, \mathrm{CH}_{3}\right), 3.97\left(\mathrm{~s}, 3 \mathrm{H}, \mathrm{OCH}_{\underline{3}}\right), 4.34\left(\mathrm{~s}, 2 \mathrm{H}, \mathrm{OCH}_{2}\right), 6.28(\mathrm{~s}, 1 \mathrm{H}$, pyrimidine-5-H), 7.12-7.85(m, 4H, phenyl-H). Anal. calcd. for $\mathrm{C}_{15} \mathrm{H}_{13} \mathrm{FN}_{4} \mathrm{O}_{3} \mathrm{~S}$ : C 51.72, H 3.74, N 16.09; found C 51.64, H 3.86, N 15.92.

Compound 6e. Yield: $78 \%$. m.p. $>250{ }^{\circ} \mathrm{C}$. IR $\left(\mathrm{cm}^{-1}\right): 1722(\mathrm{C}=\mathrm{O}), 1627(\mathrm{C}=\mathrm{N}) .{ }^{1} \mathrm{H}$ NMR $\left(d_{6^{-}}\right.$ DMSO) $\delta: 1.38\left(\mathrm{t}, 3 \mathrm{H}, \mathrm{OCH}_{2} \underline{\mathrm{CH}}_{3}\right), 4.02\left(\mathrm{q}, 2 \mathrm{H}, \mathrm{OCH}_{2} \mathrm{CH}_{3}\right), 2.25\left(\mathrm{~s}, 3 \mathrm{H}, \mathrm{CH}_{3}\right), 4.31(\mathrm{~s}, 2 \mathrm{H}$, 
$\left.\mathrm{OCH}_{2} \mathrm{CO}\right), \quad 6.34(\mathrm{~s}, \quad 1 \mathrm{H}$, pyrimidine-5-H), 7.30-8.12(m, 4H, phenyl-H). Anal. calcd. for $\mathrm{C}_{16} \mathrm{H}_{15} \mathrm{FN}_{4} \mathrm{O}_{3} \mathrm{~S}$ : C 53.04, H 4.14, N 15.47; found C 53.17, H 4.03, N 15.35.

\section{Biological Activity Test}

The biological activity was evaluated according with the standard bioactivity test procedures of Shanghai Branch of National Pesticide R\&D South Central in China. All the target compounds 5 and 6 were tested for their herbicidal activity according with the method reported in literature. ${ }^{16}$

\section{Acknowledgements}

We are grateful to National and Shanghai Key Technologies R\&D Programs for financial support, the Nos. are 2004BA308A22-8 and 034319253, respectively.

\section{References and Footnotes}

1. Upadlgaya, J. S.; Srivastava, P. K. J. Ind. Chem. Soc. 1982, 59, 767.

2. Wegner, P.; Hans, R.; Frank, H.; Joppien, H. Eur.Pat. 1986, 190611.

3. Sarkis, G. Y.; Faisal, E. D. J. Heterocyclic Chem. 1985, 22, 137.

4. Bessard, Y.; Crettaz, R. Tetrahedron 2000, 56, 4739.

5. Kamala, K.; Tayaprasad Rao, P.; Reddy, K. Synth. Commun. 1989, 19, 2621.

6. Okajima, N.; Aoki, I.; Kuragano, T.; Okada, Y. Pestic Sci. 1991, 32, 91.

7. Stidharm, M. A., Weed Sci. 1991, 39, 428.

8. Xue, S. J.; Ke, S. Y.; Duan, L. P.; Wang, X. H.; Guo, Y. L. J. Ind. Chem. Soc. 2005, 82, 79.

9. Xue, S. J.; Ke, S. Y.; Duan, L. P.; Li, J. Z. Chin. J. Org. Chem. 2004, 12, 1610.

10. Xue, S. J.; Duan, L. P.; Ke, S. Y. Chin. J. Org. Chem. 2004, 6, 686.

11. Sarkis, G. Y.; Faisal, E. D. J. Heterocyclic Chem. 1985, 22, 137.

12. Wingfield, H. N. J. Am. Chem. Soc. 1953, 75, 4364.

13. Wei, T. B.; Chen, J. C.; Wang, X. C. Synth. Commun. 1996, 26, 1147.

14. Illi, V. O. Tetrahedron Lett, 1979, 20, 2431.

15. Xue, S. J.; Tan, D. Y. J. Central China Norm.Univ. 1998, 28, 77.

16. Xue, S. J.; Ke, S. Y.; Yan, L.; Cai, Z. J.; Wei, Y. G. J. Inorg. Biochem. 2005, 99, 2276. 